\title{
Rituals and Embodied Cultural Practices at the Beginning of Life: African Perspectives
}

\author{
Magdalena Ohaja ${ }^{1, *}$ and Chinemerem Anyim ${ }^{2}$ \\ 1 School of Nursing and Midwifery, National University of Ireland Galway, H91 TK33 Galway, Ireland \\ 2 Coombe Women and Infants University Hospital, D08 XW7X Dublin, Ireland; anyimchinemerem@gmail.com \\ * Correspondence: magdalena.ohaja@nuigalway.ie
}

Citation: Ohaja, Magdalena, and Chinemerem Anyim. 2021. Rituals and Embodied Cultural Practices at the Beginning of Life: African Perspectives. Religions 12: 1024. https://doi.org/10.3390/rel12111024

Academic Editors: Joanna Wojtkowiak and Brenda Mathijssen

Received: 30 September 2021 Accepted: 6 November 2021 Published: 22 November 2021

Publisher's Note: MDPI stays neutral with regard to jurisdictional claims in published maps and institutional affiliations.

Copyright: (c) 2021 by the authors. Licensee MDPI, Basel, Switzerland. This article is an open access article distributed under the terms and conditions of the Creative Commons Attribution (CC BY) license (https:// creativecommons.org/licenses/by/ $4.0 /)$.

\begin{abstract}
Cultural beliefs and practices find expression through rituals. Rites of initiation or passage are some of the most common rituals among the indigenous African societies. Pregnancy and Childbirth are not only biological events, but also socially and culturally constructed with associated symbols that represent the social identities and cultural values of Africans. Birth is a rite of passage, and children are perceived as special gifts from the Supreme Being. As such, pregnancy and childbirth are special events cherished and celebrated through varied rituals. Drawing on empirical literature and relevant commentaries, this paper aims to discuss selected rituals and embodied practices surrounding the start of life (pregnancy, birth, and early motherhood). The paper will specifically focus on the following aspects: pregnancy rituals; birth songs and dancing; the omugwo (care after birth); the cord and placenta rituals; and the naming ceremony. Some of the pregnancy rituals are purificatory in nature and therefore beneficial for maternal and infant health. The celebrations surrounding the birth of a child are community events, marked with singing and dancing. Following childbirth, the new mothers are not expected to participate in house chores to allow them time to recuperate. In all, discourses concerning the beginning of life, i.e., pregnancy and the periods surrounding it, are filled with rituals which are embodiments or expressions of cultural values, customs, and beliefs.
\end{abstract}

Keywords: rituals; pregnancy; birth; cultural practices; Africa

\section{Introduction}

In most African nations, as in many other societies, once married, women are expected to get pregnant and bear children for the expansion and continuation of the family lineage from one generation to another (Chukwu and Ume 2020). Human existence is a journey with series of changes from the time of birth until the time of death, the two most important times in a person's life. Birth, the start of a new life is a special and unique life event, which occurs within a cultural and social context (Nwadiokwu et al. 2016; Wojtkowiak 2020). In other words, childbirth is not only a biological event, but it is also socially and culturally constructed with associated symbols and rituals that represent the social identities and cultural values of any given society (Van Beek 2002). In many communities, childbirth is "a life cycle and a communal event associated with rites of passage" (Siwila 2015, p. 64). Put differently, rituals and or cultural practices are deeply embedded with rites of passage at varied stages of a person's life: pregnancy, birth, naming ceremonies, puberty/adolescence, marriage, death, and burial (Nwadiokwu et al. 2016; Ehimuan 2021). The rituals that accompany these rites of passage play a role in giving meaning to people's ways of being (Mogawane et al. 2015), as well as the importance of indigenous knowledge in pregnancy and birthing discourse in Africa (Siwila 2015). It is also important to acknowledge the role of religion and spirituality in women's ways of being during pregnancy, childbirth, and early motherhood (Ohaja et al. 2019; Ohaja and Murphy-Lawless 2017), given that religion and spirituality are contextual practices which also find expression through rituals 
(Ehimuan 2021). As asserted by Kanyoro (2002, p. 60), the rites of passage are performed to affirm the place of an individual within a cultural and religious setting. Christianity and Islam, the two major religions practiced in Africa (Westoff and Bietsch 2015), have influenced these practices in some places (Nwoye 2014). However, it is beyond the scope of this paper to discuss the impact of these religions on pregnancy and birth rituals rather it highlights the fact that most of these practices are still ongoing. As such, the paper is not a representation of religion in Africa.

Embodiment of pregnancy has been described by Neiterman (2012, p. 372) as an act of "doing pregnancy" which involves learning, adapting, and performing. Embodiment is not a fixed entity, rather it is as argued by Turner (2004, p. 71) "a life process that requires the learning of body techniques such as walking, sitting, dancing, and eating. It is the ensemble of such corporal practices, which produce and give a body its place in everyday life ..." " During pregnancy women learn, negotiate, and renegotiate the usage of their bodies (Neiterman 2012), an experience they share with other women (embodied culture), highlighting the importance of social interaction. In other words, the pregnant women make continuous adaptation and practical adjustment to accommodate the needs of the body and by extension to maintain good health. The adjustments or changes occur in specific socio-cultural context and space which facilitates the incorporation of cultural and social meanings of pregnancy. Put simply, women learn "how to inscribe the culturally prescribed pregnancy practices on their bodies" (Neiterman 2012, p. 374). Culture is embodied in the activities of daily living, pregnancy and the periods surrounding it is no exception. In many societies, women's actions during this time are shaped by culture, and women are assisted and monitored by other female relatives in the 'doing' or 'performing' of pregnancy, birthing and early motherhood.

As noted above, discourses concerning the beginning of life, i.e., pregnancy and the periods surrounding it, are filled with rituals and cultural practices (Van Beek 2002). While some of the cultural practices are described as harmful, others have been acknowledged as having protective and therapeutic effects both for the mothers and their babies with huge benefits for the family and the community at large (Ayaz and Yaman Efe 2008; Beinempaka et al. 2015). Babies are cherished as special gifts from God the Supreme Being not only to the immediate family but also to the entire community (Chukwu and Ume 2020). As such, the birth of a child is usually announced and celebrated within the community (Igbokwe and Ahurumaraeze 2019), and the jubilation is followed by rituals which are embodied cultural practices (Beinempaka et al. 2015). Rites of passage are perceived as community building events, and not a way of diminishing individuals (Siwila 2015). van Bogaert and Ogubanjo (2008) suggest that as long as cultural beliefs and traditions do not cause harm, they should be respected and left alone, considering their spiritual role in alleviating anxiety, and enhancing a sense of purpose.

Drawing on evidence from the following countries: Cameroon, Ghana, Kenya, Madagascar, Mali, Niger, Nigeria, South Africa, Tanzania, Uganda, and Zambia, this paper will discuss rituals and embodied practices surrounding the start of life (pregnancy, birth, and early motherhood). The paper will specifically focus on the following aspects: pregnancy rituals; birth songs and dancing; the cord and placenta rituals; the omugwo (care after birth); and the naming ceremony. Given that the continent is known for its oral history, the paper will include relevant commentaries and editorials around the subject. We will begin by presenting an overview of rituals.

\section{Understanding Rituals: African Worldviews}

Africa is a continent with diverse ethnic groups, language, rituals, and cultural practices. Cultural beliefs and practices find expression through rituals, which existed prior to contact with the western world. Rituals in African cosmology are "symbolic, routine, and repetitive activities and actions through which we make connections with what we consider to be the most valuable dimension of life. They are often associated with significant events or places in our individual and communal lives" (Kyalo 2013, p. 35). As such, rituals are 
considered the most repetitive and traditional form of performance, with all aspects of life celebrated and ritualised (Ehimuan 2021). Ritual practices are transferred from one generation to the other. Bamidele (2010, p. 7) emphasised that "we practice an inherited culture when our social habits still reflect what our forefather practiced in their days." Rituals are not outdated; they remain an ongoing and crucial aspect of African existence. As noted by Victor Turner (1962), wherever novelty and individualism abound, rituals can become a thing of history in a short period of time. For Turner, rituals sustain its function only in societies where technology has had little influence. Each region has unique community-based ways of expression. Etim (2019, p. 6) argued that the employment and efficacy of rituals among the people is premised on their "world view of harmonious monism, complementarity and integrated cosmology." Ritual does not only unite people to a community of shared values, but it also connects the body and mind, as well as emotions (Kyalo 2013).

Kyalo (2013) categorised rituals into two types: (1) rites which are linked to the human life cycle: namely, beginning of life (birth), marriage, and human crises, e.g., illness and end of life (death); (2) rites connected to fixed events, which can be either yearly or historical events. In the African context, the rituals connect us to our ancestors and therefore give meaning to our existence. Becoming a mother is among the most celebrated events in many societies (Siwila 2015). Laura Grillo (2012, p. 112) described ritual as "a means to negotiate a responsible relationship in the human community, with the ancestors, spirits, divinities, and cosmos." She went on to assert that "African rituals are reflexive strategies seeking practical ends: they establish identity, elicit revelation, access divinity to foster empowerment and effect transformation" (Grillo 2012, p. 112). The two most important times in a person's life are the birth and death of the person; both events are marked with symbolic rituals. However, contemporary Africa has witnessed alterations in the ways of being during pregnancy and birth, heralded by institutionalisation and medicalisation of pregnancy and the birthing process influenced by western civilisation, which, for the most part, results in the denigration of women's subjective experiences and indigenous knowledge. For example, there has been mounted effort from advocates of biomedicine to exterminate traditional healing rituals, some cultural practices such as the use of herbal medicine are condemned, and described as evil and harmful (Asamoah-Gyadu 2014; Ohaja and Murphy-Lawless 2017; Williams 2018). Nonetheless, the use of traditional healing rituals has gained fresh momentum among the Igbo people of Nigeria (Williams 2018). In Zambia "rituals, traditions, and beliefs still have an important position in constructing social gender, cultural, moral rules and taboos" (Honkavuo 2021, p. 3).

All stages of life in Africa are ritually celebrated. The series of rites and rituals serve as a preparation for the next phase in the life of an individual (Ezenweke 2012). There are many rituals and taboos observed by women during pregnancy in an attempt to keep the mother and baby healthy and safe. Most of the traditional ritual practices are observed after childbirth at which time the new mother's main role is to breastfeed the newborn. The rituals are representations of indigenous knowledge's systems and values, as well as ways of being.

\section{Pregnancy Rituals}

Celebration of a new entrant to the community begins with conception, and pregnancy is indicative of a new member of the family and society; hence, birth rituals start with the pregnant woman (Nwadiokwu et al. 2016). As explained by Chukwu and Ume (2020), the joy of a woman expecting a baby "knows no bound as she cheerfully sings and dance harmoniously, swerving her body mass tenderly from the right to the left unknown to her that her songs have enchanted neighbours" (p. 194). In many cultures, pregnant women observe different rituals or taboos that aim to protect the mother of the child from perceived evil attack. The taboos range from wearing protective bracelets to avoiding certain foods. In her recent ethnographic study of Zambian women's experiences of cultural and traditional health beliefs about pregnancy and childbirth, Honkavuo (2021) found that in addition 
to prayers, women wore a protective band around the waist to wall off evil spirits. The study also showed that women avoid fish, birds' eggs, and meat during pregnancy while fruits and vegetables, shima (nutrient deficient cornmeal), and rice are recommended. In Abamba (Kenya), it is prohibited for pregnant women to eat beans, fat, and the meat of animals slaughtered with poisoned arrows during the last trimester of pregnancy. Dietary prohibition or proscription were reported to have protective benefits in Southern Cameroon (Elom 2019) and among the Maasai-Kenyan women (Mpoke and Johnson 1993). In addition, the Maasai women increased their water intake, and they also take bitter herbs and roots to induce vomiting. It is believed that this purifies the woman's bloodstream and cleans her stomach (Mpoke and Johnson 1993). Contrastingly, among the Ika tribe of Nigeria, expectant women can eat any food of their choice unless advised by elders or medical practitioners (Nwadiokwu et al. 2016).

Pregnant women are expected to achieve what Pourette et al. (2018, p. 57) referred to as 'culturally-defined ideal childbirth'. Based on their two anthropological studies conducted in Madagascar, culturally-defined ideal childbirth is characterised by avoidance of stillbirth or caesarean section, the baby not too thin or too big, and socially and financially inexpensive. Women achieve this by avoiding food like sweet potatoes, bananas, fatty foodstuffs such as peanuts, and salt, particularly in the third trimester. Drinking ice-cold water plays a role in the reduction of the weight and size of the foetus. The tendency by some societies to control what women can or cannot eat during pregnancy may also be harmful in the sense that such restriction on diet may deny women of useful nutritional food (Siwila 2015). That said, it can be argued that some of these taboos and rituals are purificatory in nature, provide protection for the mother and child from perceived evil powers, and are therefore beneficial for maternal and newborn health.

\section{Birth Songs and Dancing (Egwu ọiu nwa)}

Chukwu (2015) describes childbirth as an avalanche of blessing from nature to man. Throughout Africa, the news of the birth of a child is received with immense joy (Nwadiokwu et al. 2016). At the announcement of the birth of a child, women in the immediate and extended family and kindred gather to welcome the child with ululation, singing traditional songs and dancing. It is an expression of joy that the lineage is expanded. Birth songs (egwu oni $u$ nwa), as noted by Uzochukwu (2006), are sung in most cases, and the dancing rhythm of the songs makes them more fitting for the occasion, which enhances active participation of the audience (women) that gathered to celebrate the occasion given that childbirth is a communal event in nature. This is exemplified in the lyrics of some of the songs, which also signify that the newborn child does not only belong to the immediate family alone but to the entire community, and it is therefore the responsibility of every member of the community to care for the child. This is evident in the most popular song among the Igbo ethnic group of Nigeria. Through the song, all those around (women) are invited to join the celebration of the birth of the newborn as expressed in the birth song presented in Table 1.

Table 1. Birth Song 1.

\begin{tabular}{cc}
\hline Igbo & English Translation \\
\hline "Onye nuru akwa nwa eeee & "Whoever hears the cry of a baby eeee \\
Onye nuru akwa nwa mee ngwa ngwa & Whoever hears the cry of a baby, hurry \\
Obughi otu onye nwe nwa" & A child does not belong to one person" \\
\hline (Adapted from Chukwu and Ume 2020, p. 198).
\end{tabular}

Childbirth songs do not only contain celebratory lyrics, the sex of a child is also announced with birth songs. It is also a medium of offering thanks to Chineke (God who creates or God the creator). Example is presented in Table 2. 
Table 2. Birth Song 2.

\begin{tabular}{cc}
\hline Igbo & English Translation \\
\hline “Hia hia hia e e e e e & "Hia hia hia e e e e e \\
Oe Oe Oe e e e e e e & Oe Oe Oe e e e e \\
Onye ji ego bia ngaa oo & Whoever has money let him come here \\
O muru nnwa gini oo? & Did she give birth to what? \\
O muru nnwa nwoke oo. & She gave birth to a baby boy \\
O muru nnwa nwayi oo. & She gave birth to a baby girl. \\
Hia hia hia e e e e e & Hia hia hia e e e e e \\
Oe Oe Oe e e e e e e & Oe Oe Oe e e e e e \\
Chineke i meela oo." & God, you have done well." \\
\hline
\end{tabular}

(Adapted from Ebeogu 1992, p. 43).

The integrity of women and men's superiority as the guardians of society are often represented through songs (Ebeogu 1992). As such, egwu ọiu nwa offer women an opportunity to be heard. Even though it is beyond the scope of this paper to discuss the male and female child dichotomy, it is important to note that while the birth of every child is celebrated, the celebration is more elaborate and louder when the baby is a male child (Chukwu and Ume 2020). For the Basukuma people, who are described as the most joyful people in Tanzania, song and dance are naturally part of ritual ceremonies including childbirth (Mirambo 2004).

\section{The Umbilical Cord and Placenta Rituals}

The umbilical cord and placental practices form important aspect of discourse around rite of passage. These practices are often culturally controlled beliefs that function as spiritual means of control over the welfare of the infant, the mother, and the community in general (van Bogaert and Ogubanjo 2008). Kanu (2019) describes cutting of the umbilical cord as indicative of incorporating the child into the community. By this act, the child belongs to the entire community. In other word, "it is a rite of separation of the child from the world of the ancestors and incorporation into the world of human beings" (Kanu 2019, p. 26).

For decades, the human placenta has received traditional handling by various cultures around the world. In western medicine, the human placenta is typically viewed as just human waste. However, in many African societies, the umbilical cord and placenta are viewed as holders of extraordinary power (Adamson 1985), and therefore they are handled carefully. The placenta is referred to as a "traveling companion" which assists the ushering of the new baby from one world to the next as shown in a historical ethnographic study of the Sahel-Niger community (Cooper 2019). For the Ugandans, the placenta is regarded as another baby and therefore given formal burial (Beinempaka et al. 2015). In Kenyan Luo cosmology, the left side relates to vulnerability and impermanency while the right side indicates authority and permanency. Consequently, the placenta of a female infant is buried on the left-hand side of her mother's house, while the placenta of a male infant is buried on the right-hand side. Girl children are perceived as temporary or transient members of the community because they move outside the family for the purpose of marriage, but boys will remain in the family to maintain the ancestral lineage and continue as patriarchal authorities (Nangendo 2005; Mulemi and Nangendo 2001). Furthermore, the burial of the umbilical cord and placenta is believed to restore a woman's fertility, bring about healing of the womb, and preserve the future of the newborn.

There are varied burial sites for the placenta among the Tonga people of Zambia. Depending on the clan, it can be buried under the mupundu tree, on the veranda of the family hut, or at its centre. The mupundu tree is known as fertility tree, hence its link with women's fertility. Using the mupundu tree as a placenta burial site illustrates the connection between nature and birthing (Siwila 2015). This act is symbolic as it is "a way of evoking the spirit world through nature to continue blessing the womb of the woman so that she can be as fruitful as the mupundu tree" (Siwila 2015, p. 65). Similarly, the Igbo ethnic group 
in Nigeria and the Ghanaians consider the placenta as the deceased twin of the newborn, and they bury it mostly under a tree, as trees symbolize ongoing life. In Ghana, burying the placenta at home is a way of preserving the child's destiny (Adatara et al. 2019).

For the Igbos, the tree where the placenta is buried belongs to the child, it connects the child and the earth. In Mali, it is believed that the placenta can influence the child's mind-set or even make the child sick. Therefore, the placenta is washed, dried, put in a bowl and buried by the man of the house. The Kikuyu people of Kenya places the placenta in an uncultivated field and cover it with grasses and grains (Liesje 2014). All in all, the placenta is highly revered in most African societies because of its biological and spiritual connection to a child's life cycle.

\section{The Omugwo Ritual (Care after Birth)}

The period after birth is known as the postnatal period and universally defined as lasting 40 days with striking similarities as well as differences between varied cultures (Eberhard-Gran et al. 2010). It is the custom in many countries for women to be cared for by their mothers or mothers-in-law, who take responsibility of the house chores as well as look after the new mother and her baby, thereby allowing the new mother time to recuperate (Umunna 2012; Igbokwe and Ahurumaraeze 2019). For the Igbo ethnic group of southeast Nigeria, this period is called the omugwo period, and the practice surrounding it is known as the omugwo ritual (care after childbirth), or "a special rehabilitation of the woman after childbirth" (Ekweariri 2020, p. 5). The duration of omugwo differs and ranges from a minimum of seven weeks to six months. Kelly (1967) noted that in Nigeria a woman and her newborn are confined to a 'fattening room' to facilitate rest and recuperation and weight gain (Kelly 1967).

Many African societies believe that it takes a village to raise a child. Communal living and togetherness are central elements of many societies and cultures. As highlighted by Umunna (2012, p. 9), "nowhere is this commitment to collective communal social responsibility more evident than in the omugwo practice." It is a feasting period marked with many rites such as ceremony of reincarnation, burying of the umbilical cord, circumcision, and naming of the child. The period culminates with the outing ceremony of the mother (Mbah 1993). It is in this spirit that the omugwo practice is so important in traditional Nigerian Igbo society, to the extent that the new mother is not allowed to participate in house chores, including cooking for the family, fetching water, and working in the farm, among others (Igbokwe and Ahurumaraeze 2019; Kanu 2019). Similarly, in Kenya and Tanzania, as reported by Bergsjø (1993), the Masai women are isolated and encouraged to take some respite, and to pay attention to their nutrition after childbirth. The mother of the new mother or other older female relatives take over these roles including caring for the newborn, which enhances the resting period of the new mother, and her role is primarily to breastfeed the baby (Chukwu and Ume 2020). The woman attending the omugwo of her daughter usually prepares some local delicacies, which will help the new mother's body to return to normal post childbirth (Ujumadu 2018). As noted by Chukwu and Ume (2020, p. 201) "Womenfolk in the family and neighbourhood help out in preparing her food and generally keeping the home. Her food consists of hot, peppery, sumptuous soup with plenty of fish and spices like uda, utazi, nchuanwu and uziza. Hot food is believed to be good for the cleansing of the stomach. She is bathed and her stomach is massaged with hot water regularly to reduce the flab and return it to normal size." In the Manxili area of KwaZulu South Africa, women observe a similar period of rest to promote recovery (Selepe and Thomas 2000).

Migration and western ways of life have had influence on cultural practices and rituals (Nwadiokwu et al. 2016). Women who gave birth outside their country of origin need to negotiate the maternity settings in their host or adopted countries to preserve and re-pattern their pregnancy and birthing cultural rituals. Despite some level of disruption by migration, omugwo practice remains a very crucial ritual for new mothers (Igbokwe and Ahurumaraeze 2019). Observation of cultural rites and rituals may not only act as a useful guide in terms of supporting women during pregnancy and birth experiences, but it also 
has the potential for aiding women's transitions to motherhood. Dike (2019) carried out a qualitative study of the birth experiences of first-generation Nigerian women (FGNW) who are residents in London. The study aimed to explore the influence of cultural practices on women's birth experiences. The findings revealed the significance of cultural influence on the birth and maternity experiences of FGNW. The "tradition of nourishing a new mother appear to be upheld with a measure of ritualistic significance orchestrated via the Omugwo ceremony (where rest and recuperation is maintained over a given period of about a month to three months with female relatives taking care of the new mother)" (Dike 2019, p. 94).

The end of omugwo period is marked with a ceremony for the purpose of cleansing and purifying the new mother, who, at this point, is considered competent to resume her responsibilities within and outside the house (Anozie 2003). The rest period is followed by Ukuphuca - a celebration to mark the completion of the postnatal period in KwaZulu (Selepe and Thomas 2000). It can be argued that the most important benefit of the omugwo period is that it enhances maternal rest, the maternal-infant relationship, and the establishment of breastfeeding (Beinempaka et al. 2015).

\section{The Naming Ceremony}

All African societies believe that every new member of the society is unique with a specific mission, and that names have rich cultural content (Bamidele 2010). The newborn infant is initiated to the society and the world at large through the naming ceremony ritual. Therefore, the naming ceremony is a ritual performed to give a name, and to welcome the child to the community (Nwoye 2014).

While a baby is named after three days of birth in Akamba, Kenya, and parts of Tanzania, in Yoruba southwestern Nigeria, the naming ceremony occurs seven days after birth (Baiyewu 2020). For the Nri and Ihiala (Igbo) people, naming takes place on the 12th day (Nwoye 2014). Names represent people's personality or character, and sometimes directs the paths to follow (Baiyewu 2020). The circumstances that surround a baby's birth are taken into consideration when naming the child (Kanu 2019; Baiyewu 2020). Therefore, traditional African communities pay attention and select names carefully for their children. As asserted by Bamidele (2010, p. 9) "an indigenous African name on the whole personifies the individual, tells some story about the parents and or the family of the bearer, and in a more general sense, points to the values of the society into which the individual is born."

In some cultures, the family and community contact the diviners to determine the infant's unique mission prior to the naming ceremony of a child. Leena Honkavuo (2021, p. 10) in her recent Zambian ethnographic study reported that the ancestors are contacted by the healer "to ensure the child's future with the name." The newborn inherits a name from the family. The name cannot be given if the child cries or is ill. It is the responsibility of the healer to discuss with the ancestor regarding whose name the child will be given (Honkavuo 2021). This is in line with the practice of the people of Omuma division in Imo State, Nigeria, who believe in reincarnation. They consult an oracle to determine who reincarnated (Anyachonkeya 2014). Kanu (2019, p. 39) argues that "naming is prophetic", i.e., the name is given as a prayer that aims to bless the child's future, or to counter bad luck, e.g., Chidindu (God lives). A name is an icon or monument for remembering an event or circumstances surrounding the period of birth. Therefore, names have a historical undertone (Kanu 2019).

\section{Discussion}

The primary aim of this paper was to discuss the rituals and embodied practices surrounding the start of life (pregnancy, birth, and early motherhood) drawing on evidence from the following countries: Cameroon, Ghana, Kenya, Madagascar, Mali, Niger, Nigeria, South Africa, Tanzania, Uganda, and Zambia. Migration has had an influence on cultural practices and rituals including pregnancy and birthing-related cultural practices. Worthy of note is that a number of rituals still remain in existence despite urbanisation and migration. Maalouf (2012) in a discourse of the complexities around identity noted that human beings 
have two heritages. The first, a vertical heritage which has ancestral origin, popular traditions, and affiliation with religion, while the second heritage is horizontal in nature, and it is acquired by people through social groups and modern society. Rituals in Africa have both elements, ancestral origin, and passed from one generation to another. Cultural beliefs and practices find expression through rituals, which connect us to our ancestors and give deeper meaning to our existence. Rites of initiation or passage are among the most common rituals practiced by indigenous societies. In connection with the value of indigenous knowledge, a variety of rituals are performed by women until the birth of the baby and early motherhood (Siwila 2015). In this paper, we focused specifically on pregnancy rituals, and rituals performed after childbirth, namely, birth songs and dancing, the umbilical cord and placenta rituals, the omugwo ritual (care after birth), and the naming ceremony.

The first major African initiation rite is the rite of birth. As an act of eloquent expression, rituals are a means of transmitting cultural beliefs and values with dramatic effect and emotive force (Grillo 2012). Despite criticism regarding adherence to ritual practices and taboos, it has been shown that some of the pregnancy and birth rituals have purificatory effects, provide protection for the mother and child from evil powers, and are therefore beneficial for maternal and newborn health (Nwadiokwu et al. 2016; Honkavuo 2021). Dietary proscription is among the precautionary measures observed by women to promote health and ensure a normal and safe birth (Elom 2019; Honkavuo 2021).

In Africa, the birth of a new baby is often welcomed with jubilation. It is a special event celebrated by the family and the entire community with joy, singing, and dancing. Ebeogu (2017) opines that birth songs are so popular among the Igbo ethnic group of Nigeria to the extent that any discussion around the dominant types or categories of oral poetry which do not include birth songs would be faulted for neglecting a crucial aspect of that poetry. In most African societies an individual is non-existent without the community. The coming together of the community to welcome the newborn is indicative of the commitment to communal living, which is the essence of the traditional African way of life (Agulanna 2010).

The umbilical cord and the placenta are carefully handled and treated with great respect, signifying their value (biologically) as important part of an infant's life cycle. Burying of the placenta is seen as a life-giving ritual which symbolises the continuation of life. During this transition period, both the mother and child are said to be in a liminal space (Siwila 2015). The burial of the umbilical cord and placenta denotes connection to the ancestors or family lineage and mother earth. Put differently, burying the placenta connects the baby to the spirit world. It helps in preserving the child's destiny (Adatara et al. 2019). This is a special ritual which unites the members of the community. Their umbilical cord and the placenta which nurtured them as foetuses in the womb are buried in the same village.

The spirit of communal living and togetherness is also demonstrated in the omugwo ritual, whereby a new mother is cared for by her own mother, or mother in-law for a period of time. Other older female relatives also offer support by bringing food items as well as helping with house chores. This act of family and community support allows women the time to recover. This period of rest and recovery is a common practice in many cultures including Kenya and Tanzania (Bergsjø 1993), Nigeria (Igbokwe and Ahurumaraeze 2019; Kanu 2019; Chukwu and Ume 2020), and South Africa (Selepe and Thomas 2000). Evidence has shown that support given to new mothers has health benefits for women (Dennis et al. 2007; Dike 2019). In their systematic review of 51 studies carried out in more than 20 different countries, Dennis et al. (2007) found that organized support for the mother, periods of rest, recommended food to be eaten or avoided, hygiene practices, and infant care and breastfeeding are the postpartum period care or rituals which allowed "the mother to be 'mothered' for a period of time after the birth" (p. 487). These rituals facilitate the transition to motherhood and may have beneficial health effects for the women and their newborn babies (Umunna 2012; Beinempaka et al. 2015; Igbokwe and Ahurumaraeze 2019). 
Adequate support after childbirth has the potential of preventing anxiety, and by extension postnatal depression (Odinka et al. 2019). Migration has been acknowledged as presenting some challenges to the practice of the omugwo ritual (Dike 2019).

Most tribes believe that the circumstances surrounding the birth of a child also influence the name given to the child (Kanu 2019). Importantly, names are not only identity, but they also influence people's character and life in general. Some cultures consult the ancestors for assistance in determining what name best suits the child (Anyachonkeya 2014; Honkavuo 2021). Examples of pregnancy and birth rituals and reasons are presented in the Table 3 below.

Table 3. Some examples of pregnancy and birth rituals according to countries.

\begin{tabular}{|c|c|c|}
\hline Ritual/Cultural Practice & Rationale & Ethnic Group/Country \\
\hline \multicolumn{3}{|l|}{ Pregnancy Rituals } \\
\hline \multicolumn{3}{|l|}{ Dietary prohibition } \\
\hline $\begin{array}{l}\text { Avoidance of sweet potatoes, bananas, fatty } \\
\text { foodstuffs, and salt, particularly in the third } \\
\text { trimester. }\end{array}$ & To prevent stillbirth or big baby & Madagascar \\
\hline Avoidance fish, birds' eggs, and meat & Risk of premature birth. & Zambia \\
\hline Meat of bubale & $\begin{array}{l}\text { Risk of bleeding, miscarriage, and } \\
\text { difficult childbirth }\end{array}$ & Cameroon \\
\hline \multicolumn{3}{|l|}{ Recommended diet } \\
\hline Increased water intake, bitter herbs, and roots & $\begin{array}{l}\text { Induce vomiting to purify the woman's } \\
\text { bloodstream and cleanse her stomach }\end{array}$ & Maasai, Kenya \\
\hline Drinking Ice cold water & Reduce foetal weight and size & Madagascar \\
\hline Any food of their choice & & Ika tribe-Nigeria \\
\hline Wearing of bracelets & Protection against evil & Zambia \\
\hline Birth songs and dance & $\begin{array}{l}\text { Expression of joy following successful } \\
\text { and safe childbirth }\end{array}$ & $\begin{array}{c}\text { Igbo-Nigeria } \\
\text { Basukuma-Tanzania }\end{array}$ \\
\hline \multicolumn{3}{|l|}{ Umbilical Cord and Placenta rituals } \\
\hline $\begin{array}{c}\text { Placenta-washed, dried, put in a bowl and } \\
\text { buried by the man }\end{array}$ & $\begin{array}{c}\text { Influence the child's mind-set or make } \\
\text { the child sick }\end{array}$ & Mali \\
\hline Placenta buried under a mupunda tree & $\begin{array}{l}\text { Mupunda is a fertility tree. The tree } \\
\text { symbolises ongoing life }\end{array}$ & $\begin{array}{l}\text { Ghana, Igbo-Nigeria, } \\
\text { Tonga-Zambia }\end{array}$ \\
\hline $\begin{array}{l}\text { Placenta placed in uncultivated covered with } \\
\text { grasses and grain }\end{array}$ & & Kikuyu, Kenya \\
\hline The Omugwo rituals & Rest period for the new mother & $\begin{array}{c}\text { Nigeria } \\
\text { Kwazulu-South Africa }\end{array}$ \\
\hline \multirow{3}{*}{$\begin{array}{l}\text { The Naming ceremony } \\
\text { Consultation with ancestors }\end{array}$} & $\begin{array}{l}\text { to determine which names should be } \\
\text { given to the child }\end{array}$ & \\
\hline & $\begin{array}{l}\text { To determine which name to be given to } \\
\text { the child }\end{array}$ & Omuma-Nigeria \\
\hline & $\begin{array}{l}\text { To ensure the child's future with the } \\
\text { name }\end{array}$ & Zambia \\
\hline
\end{tabular}

\section{Conclusions}

In this paper, we discussed rituals and embodied practices surrounding the start of life (pregnancy, birth, and early motherhood) in some African countries. Rituals are eloquent expressions of cultural beliefs and values passed on from one generation to another, and which have remained an ongoing and crucial aspect of African existence. Pregnancy and birth rituals are not only representative of an indigenous system of knowledge, but also 
play a role in giving meaning to a people's ways of being. There are many documented benefits of pregnancy and birth ritual. While some of the rites and rituals facilitate safe birth and protect the mother and child from perceived evil powers, others offer the space for connecting with ancestral spirits. Crucially, birth-related rituals have spiritual connection, and they enhance togetherness, which is an important element of the African way of life. Women should be supported to observe the rituals that are beneficial to their health and that of their babies.

Author Contributions: Conceptualisation-M.O., writing-original draft preparation M.O. and C.A.: formal analysis M.O.; writing-review and editing M.O. and C.A. All authors have read and agreed to the published version of the manuscript.

Funding: This research received no external funding.

Institutional Review Board Statement: Not applicable.

Informed Consent Statement: Not applicable.

Data Availability Statement: Not applicable.

Conflicts of Interest: The authors declare no conflict of interest.

\section{References}

Adamson, P. B. 1985. Some rituals associated with parturition in antiquity. Folklore 96: 176-93. [CrossRef]

Adatara, Peter, Johanita Strumpher, Esmeralda Ricks, and Prudence Portia Mwini-Nyaledzigbor. 2019. Cultural beliefs and practices of women influencing home births in rural Northern Ghana. International Journal of Women's Health 11: 353-61. [CrossRef]

Agulanna, Christopher. 2010. Community and human well-being in an African culture. Trames 14: 282-98. [CrossRef]

Anozie, Christiana Chukwudi. 2003. Igbo Kwenu: Akuko na Omenaala Ndi Igbo. Enugu: Computer Edge Publishers.

Anyachonkeya, Ngozi. 2014. Naming in Igbo Land: A linguistic and cultural study. Mediterranean Journal of Social Sciences 5: 113-22.

Asamoah-Gyadu, Kwabena Johnson. 2014. Therapeutic Strategies in African Religions: Health, Herbal Medicines and Indigenous Christian Spirituality. Studies in World Christianity 20: 70-90. [CrossRef]

Ayaz, Sultan, and Sengul Yaman Efe. 2008. Potential harmful traditional practices during pregnancy and postpartum. The European Journal of Contraception \& Reproductive Health Care 13: 282-88.

Baiyewu, Annabelle. 2020. Baby Naming Ceremony Traditions in Africa. Available online: https://www.waafashion.com/blogs/ news/naming-ceremony-traditions-in-africa (accessed on 21 August 2021).

Bamidele, Rasak. 2010. Naming Ceremony: Comparative Analysis of the Igbo and Yoruba Culture in Nigeria. Continental Journal of Arts and Humanities 2: 7-16.

Beinempaka, Florence, Basil Tibanyendera, Fortunate Atwine, Teddy Kyomuhangi, Jerome Kabakyenga, and Noni E. MacDonald. 2015. Traditional Rituals and Customs for Pregnant Women in Selected Villages in Southwest Uganda. Journal of obstetrics and gynaecology Canada: JOGC 37: 899-900. [CrossRef]

Bergsjø, Per. 1993. African intermezzo: Home birth, Masai style. Acta Obstetricia et Gynecologica Scandinavica 72: 597-598. [CrossRef]

Chukwu, Christian Chima, and Ignatius Sunday Ume. 2020. Celebration of childbirth through dance and the demystification of the male child in the Igbo Patriarchal Society: A decisive exposition. Revista Brasileira de Gestão Ambiental et Sustentabilidade 7: 193-209. [CrossRef]

Chukwu, Christian Chima. 2015. Sociological evaluation of the inordinate quest for the birth of the boy child amongst couples in the Igbo Ethnic Group of Southeast, Nigeria: A critical overview. International Journal of Humanities and Social Studies 1: 1.

Cooper, Barbara. 2019. Travelling companions: The burial of the placenta in Niger. African Studies Review 62: 127-48. [CrossRef]

Dennis, Cindy-Lee, Kenneth Fung, Sophie Grigoriadis, Gail Erlick Robinson, Sarah Romans, and Lori Ross. 2007. Traditional postpartum practices and rituals: A qualitative systematic review. Women's Health 3: 487-502. [CrossRef]

Dike, Priscilla. 2019. Does culture influence birth experiences of first generation Nigerian women in London. International Journal of Nursing and Midiwfery 2: 87-102.

Ebeogu, Afam. 1992. Feminist Temperament in Igbo Birth Songs. In Power and Powerlessness of Women in West African Orality. Edited by Nnadozie Inyama and Raoul Granqvist. Umea: The Printing Office of Umea University, pp. 43-62.

Ebeogu, Afam. 2017. Poetry of occasion: The feminist temperament in Igbo birth songs. In Ethnosensitive of African Oral Literature-Igbo Perspectives. London: African Heritage Press, pp. 139-62.

Eberhard-Gran, Malin, Susan Garthus-Niegel, Kristian Garthus-Niegel, and Anne Eskild. 2010. Postnatal care: A cross-cultural and historical perspective. Archives of Women's Mental Health 13: 459-66. [CrossRef] [PubMed]

Ehimuan, Freda. 2021. In Africa, Cultural Expressions Accompany Christian Practices. Available online: https://www. globalsistersreport.org/news/spirituality/arts-and-media/column/africa-cultural-expressions-accompany-christianpractices (accessed on 2 August 2021). 
Ekweariri, Dominic. 2020. The Passive Origin of the Institutionalization of Power Inequality in the Meaning/Experience of Womanhood in Igboland. Frontiers in Sociology 5: 1-13. [CrossRef]

Elom, Paul Ulrich Otye. 2019. Pre-Natal and Post-Natal Birth Among Bulu from South Cameroon: An Ethno-Anthropological Reading of the Birth in Negro-Culture. Journal of Archaeology E Anthropoology 1: 2.

Etim, Francis. 2019. Ontology of Africa rituals. Advances in Applied Sociology 9: 1-14. [CrossRef]

Ezenweke, Elizabeth O. 2012. Rites and rituals in African ontology. In Issues in African Traditional Religion and Philosophy. Edited by Elizabeth Onyedimma and Ikechukwu Anthony Kanu. Awka: Fab Educational Books, pp. 121-46.

Grillo, Laura. 2012. African rituals. In Companon to African Religion. Edited by Kifon Bongmba. West Sussex: Wiley Blackwell.

Honkavuo, Leena. 2021. Women's experiences of cultural and traditional health beliefs about pregnancy and childbirth in Zambia: An ethnographic study. Health Care for Women International 42: 374-89. [CrossRef]

Igbokwe, Benedict, and Chinwe Ahurumaraeze. 2019. Culture and migration: The case of Igbo of South Eastern Nigeria. Journal of African Studies and Sustainable Development 2: 130-47.

Kanu, Ikechukwu Anthony. 2019. An Igwebuike Approach to the Study of African Traditional Naming Ceremony and Baptism. Journal of Religion and Human Relations 11: 25-52.

Kanyoro, Musimbi. 2002. Introducing Feminist Cultural Hermeneutics: An African Perspective. London: Sheffield Academic Press.

Kelly, John. 1967. The influence of native customs on obstetrics in Nigeria. Obstetrics and Gynecology 30: 608-12.

Kyalo, Paul. 2013. Initiation rites and rituals in African cosmology. International Journal of Philosophy and Theology 1: 34-46.

Liesje, Bradley. 2014. Placenta Traditions. Available online: https://birthtoearth.com/blogs/resources/13984517-placenta-traditions (accessed on 2 August 2021).

Maalouf, Amin. 2012. Violence and the Need to Belong: In the Name of Identity. London: Penguin Books.

Mbah, Vincent De Paul. 1993. Igbo Child Initiation, Christian, and Baptism: A Case Study in Inculturation.. Extracto de la Tesis Doctoral presentada en la Facultad de Teología de la Universidad de Navarra. Ph.D. Thesis, Faculty of Theology, University of Navarra, Pamplona, Spain.

Mirambo, Immaculate. 2004. Oral Literature of the Sukuma. Folklore: Electronic Journal of Folklore 26: 113-22. [CrossRef]

Mogawane, Mamagoro, Tebogo Maria Mothiba, and Malema Rambelani Nancy. 2015. Indigenous practices of pregnant women at Dilokong hospital in Limpopo province, South Africa. Curationis 38: 2. [CrossRef]

Mpoke, Silole, and Karin Johnson. 1993. Baseline survey of pregnancy practices among Kenyan Maasai. Western Journal of Nursing Research 15: 298-313. [CrossRef] [PubMed]

Mulemi, Benson, and Stevie Nangendo. 2001. Therapeutic strategies and traditional medical knowledge of the people of Bar Chando Sub-location Bondo District, Kenya. Curare 24: 47-56.

Nangendo, Stevie. 2005. The tradition of Ramogi: Beliefs and practices of the levirate amongst the Luo in Bondo Division, Bondo District, Western Kenya. Mila 6: 23-32.

Neiterman, Elena. 2012. Doing pregnancy: Pregnant embodiment as performance. Women's Studies International Forum 35: 327-83. [CrossRef]

Nwadiokwu, Charles, E. S. Nwadiokwu, E. N. Favour, and M. E. Okwuazun. 2016. Rites of passage African traditional region. International Journal of Education and Research 4: 41-50.

Nwoye, Chinwe Miriam. 2014. An ethnographic study of Igbo naming ceremony (Iba nwa afa). International Journal of Sociology and Anthropology 6: 276-95.

Odinka, Paul, Jaclyn Odinka, Mark Ezeme, Appolos Ndukuba, Kennedy Amadi, Rosemary Muomah, Stanley Nwoha, and Ujunwa Nduanya. 2019. Socio-demographic correlates of postpartum psychological distress among apparently healthy mothers in two tertiary hospitals in Enugu, South-East Nigeria. African Health Sciences 19: 2515-525. [CrossRef]

Ohaja, Magdalena, and Jo Murphy-Lawless. 2017. Unilateral collaboration: The practices and understandings of traditional birth attendants in southeastern Nigeria. Women and Birth 30: e165-e171. [CrossRef] [PubMed]

Ohaja, Magdalena, Jo Murphy-Lawless, and Margaret Dunlea. 2019. Religion and Spirituality in Pregnancy and Birth: The Views of Birth Practitioners in Southeast Nigeria. Religions 10: 82. [CrossRef]

Pourette, Dolores, Carole Peirlovisi, Ranjatiana Randriantsara, Elliot Rakotomanana, and Chiarella Mattern. 2018. Avoiding a 'big' baby: Local perception and social responses toward childbirth-related complications in Menabe, Madagascar. Social Science and Medicine 218: 52-61. [CrossRef]

Selepe, Hilda Lindiwe, and Debra Thomas. 2000. The beliefs and practices of traditional birth attendants in the Manxili area of KwaZulu, South Africa: A qualitative study. Journal of Transcultural Nursing 11: 96-101. [CrossRef] [PubMed]

Siwila, Lillian. 2015. The role of indigenous knowledge in African women's theology of understanding motherhood and maternal health. Alternation Special Edition 14: 65.

Turner, Bryan. 2004. The New Medical Sociology: Social Forms of Health and Illness. New York: W.W. Norton.

Turner, Victor. 1962. The Ritual Process. London: Routledge and Kegan Paul.

Ujumadu, Vincent. 2018. Omugwo: When a New Mother Is Pampered. Available online: https://www.vanguardngr.com/2018/08/ omugwo-when-a-new-mother-is-pampered/ (accessed on 11 August 2021).

Umunna, Dehila. 2012. Rethinking the neighborhood watch: How lessons from the Nigeria village can creatively empower community to assist poor single mothers in America. Journal of Gender of Social Policcy Ethe Law 20: 847-69.

Uzochukwu, Sam. 2006. Traditional Birth Poetry of the Igbo. Lagos: Sam Orient Publishers. 
Van Beek, Walter. 2002. Why a twin is not a child: Symbols in Kapsiki birth rituals. Journal des Africanistes 72: 119-47. [CrossRef] van Bogaert, Knapp Donna, and Gboyega Ogubanjo. 2008. Post-birth Rituals: Ethics and the Law. South African Family Practice 50: 45-46. [CrossRef]

Westoff, Charles, and Kristin Bietsch. 2015. Religion and Reproductive Behavior in Sub-Saharan Africa. DHS Analytical Studies No. 48. Rockville: ICF International.

Williams, Ogechukwu Ezekwem. 2018. A blur between the spiritual and the physical: Birthing practice among the Igbo of Nigeria in the Twentieth century. In Sacred Inception: Reclaiming the Spirituality of Birth in the Modern World. Edited by Elaporte Marianne and Martin Morag. London: Lexington Books, pp. 97-112, ISBN 1498546692.

Wojtkowiak, Joanna. 2020. Ritualizing Pregnancy and Childbirth in Secular Societies: Exploring Embodied Spirituality at the Start of Life. Religions 11: 458. [CrossRef] 